\title{
Demonstration of Coexisting Catecholamine (Dopamine), Amino Acid (GABA), and Peptide (NPY) Involved in Inhibition of Melanotrope Cell Activity in Xenopus laevis: A Quantitative Ultrastructural, Freeze-Substitution Immunocytochemical Study
}

\author{
Eveline P. C. T. de Rijk, Frank J. C. van Strien, and Eric W. Roubos \\ Department of Animal Physiology, Faculty of Science, University of Nijmegen, Toernooiveld, 6525 ED Nijmegen, The \\ Netherlands
}

This quantitative ultrastructural immunocytochemical study demonstrates the coexistence of a catecholamine [dopamine (DA)], an amino acid (GABA), and a neuropeptide [neuropeptide $Y$ (NPY)] in axon varicosities innervating the pars intermedia of $X e n o p u s ~ l a e v i s$. The varicosities are assumed to control the pars intermedia melanotrope cells, which regulate skin color during the physiological process of background adaptation. Varicosity profiles appear to abut melanotrope cells and folliculostellate cells, star-shaped cells that intimately contact the melanotropes. All varicosity profiles contain two morphological types of vesicle. Monolabeling studies on routinely fixed and freeze-substituted tissues showed that the small, electron-lucent vesicles store GABA, whereas DA and NPY occur in larger, electron-dense ones. Double and triple labeling experiments, in which the degree of immunoreactivity was quantified per varicosity profile and per vesicle, led to the conclusion that (1) DA, GABA, and NPY coexist within almost all varicosity profiles and (2) DA and NPY are costored within electron-dense vesicles. Varicosity profiles that abut melanotrope cells show a much higher ratio between the numbers of electron-lucent and electron-dense vesicles than varicosities contacting folliculostellate cells (15.8 and 3.3, respectively). This differentlal distribution is in line with the previous demonstration that, in contrast to GABA, NPY does not act directly on the melanotrope cells but indirectly, by controlling the activity of the folliculostellate cells.

In the field of neuroscience, intensive research is being carried out on the chemical identification and localization of neurochemical messengers. Since the introduction of immunocytochemical techniques at both light and electron microscopic levels, it is becoming increasingly clear that many neuronal systems produce and release more than one neurochemical messenger (for review, see, e.g., Hökfelt et al., 1986). In particular performance of double labeling techniques has revealed that different

\footnotetext{
Received July 16, 1991; revised Oct. 9, 1991; accepted Oct. 10, 1991.

We thank Mr. Theo G. M. Hafmans for excellent technical assistance and Mr. Ron J. C. Engels for the Xenopus husbandry. The investigations were supported by the Foundation for Biological Research (BION), which is subsidized by the Netherlands Organization for Scientific Research (NWO) and by the European Community (Contract ST2J-0468-C).

Correspondence should be addressed to Eveline P. C. T. de Rijk at the above address.

Copyright $\odot 1992$ Society for Neuroscience $0270-6474 / 92 / 120864-08 \$ 05.00 / 0$
}

classical neurotransmitters, such as $\mathrm{ACh}$, catecholamines, and amino acids (e.g., Everitt et al., 1984; Takeda et al., 1984; Vuillez et al., 1987) as well as different peptides (e.g., Scheller et al., 1983; Hökfelt et al., 1986) can coexist within the same neuron. In some cases even coexistence of a classical transmitter and one or more peptides has been demonstrated. For instance, catecholamines as well as amino acids may occur together with neuropeptides (Hökfelt et al., 1983; Meister et al., 1985; Kagotani et al., 1989; Merighi et al., 1989; de Rijk et al., 1990). However, until now no coexistence of a catecholaminc, an amino acid, and a peptide in a single nerve terminal has been shown. In the present study we report on such a coexistence, namely, in nerve terminals in the intermediate lobe of the pituitary of the clawed toad Xenopus laevis.

In general, the physiological significance of coexisting neurochemical messengers is unclear. Obviously, coexisting factors may be released either coordinately or in a differential fashion. In both cases they may stimulate, inhibit, and/or modulate their target cells (Hökfelt et al., 1986; Brussaard et al., 1991). A widespread problem in defining the exact role of coexisting messengers is that the physiological significance of the respective neuronal systems and their targets is generally not well understood. During recent years knowledge has been obtained about the physiology of the neuronal system controlling the pars intermedia of the pituitary of the South African clawed toad Xenopus laevis.

The pars intermedia of $X$. laevis contains neuroendocrine melanotrope cells. These cells produce and release the melanophore-stimulating hormone ( $\alpha \mathrm{MSH})$, which causes skin darkening during the process of background adaptation. Superfusion experiments have revealed that at least five neurochemical messengers affect the release of $\alpha \mathrm{MSH}$. The thyrotropin-releasing hormone (TRI) and corticotropin-releasing factor (CRF) stimulate $\alpha \mathrm{MSH}$ release (Verburg-van Kemenade et al., 1987b,c), whereas dopamine (DA), GABA, and neuropeptide Y (NPY) inhibit this process (Verburg-van Kemenade et al., 1986a-c; 1987a,d). Immunocytochemical studies have indicated that TRH and CRF reach the melanotropes via the blood but that DA, GABA, and NPY are released within the pars intermedia (de Rijk et al., 1990). GABA and DA appear to act directly on the melanotropes (de Koning et al., 1991), whereas NPY exerts its inhibiting action on $\alpha \mathrm{MSH}$ release by acting upon the folliculostellate cells, glia-like cells that closely contact the melanotropes (de Rijk et al., 1990, 1991). Previously, we have shown that GABA and NPY coexist in nerve terminals abutting the 


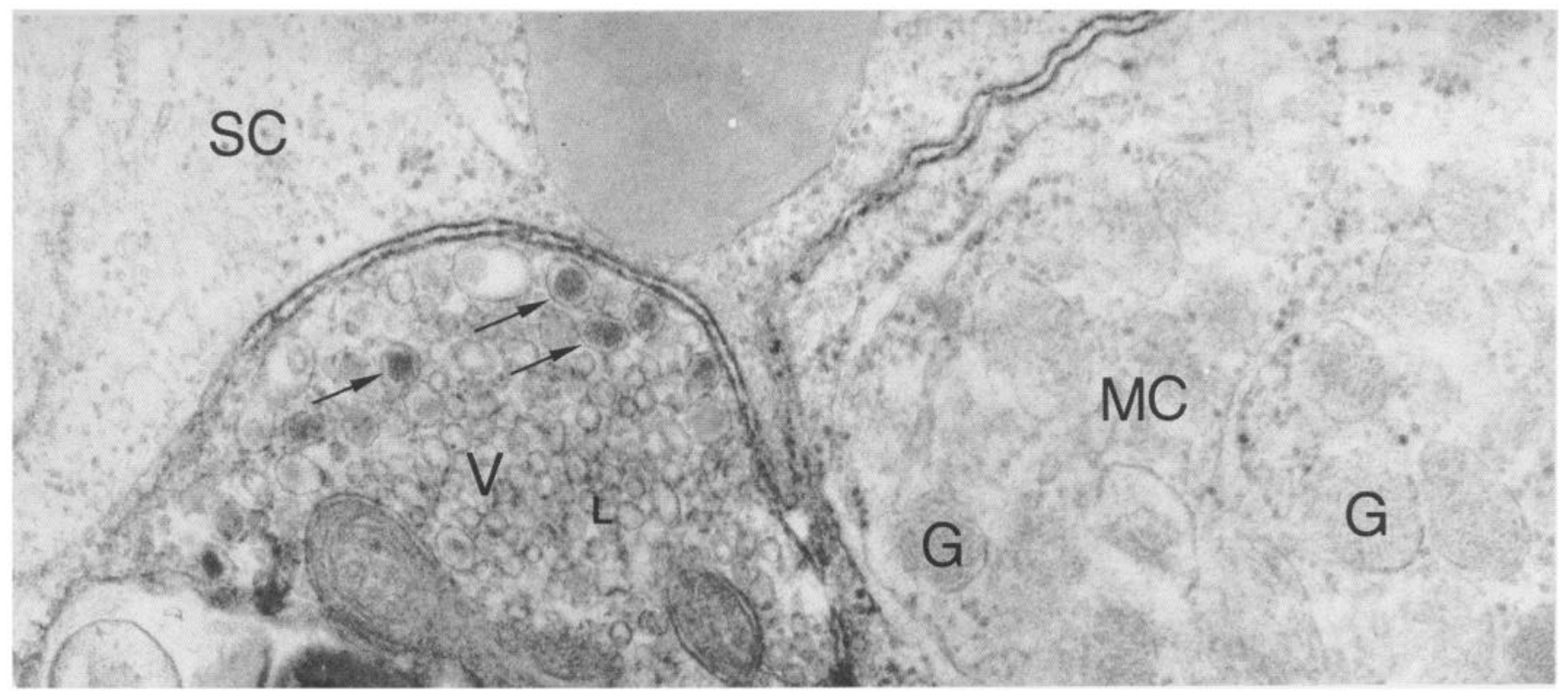

Figure 1. Pars intermedia of Xenopus laevis showing a melanotrope cell (MC), a folliculostellate cell ( $S C$ ), and an axonal varicosity profile ( $V$ ). $G$, secretory granule; $L$, cluster of LVs; arrows, DVs. Magnification, 70,000×.

melanotrope cells and folliculostellate cells (de Rijk et al., 1990). In the present immunoelectron microscope study, the coexistence of DA with GABA and NPY was investigated using a double and triple immunogold labeling procedure on freezesubstituted and low-temperature-embedded material. Furthermore, attention was paid to the differential presence of messenger-containing secretory vesicles in synaptic contacts on melanotropes and folliculostellate cells.

\section{Materials and Methods}

Animals. Adult Xenopus laevis with a weight of approximately $30 \mathrm{gm}$ were obtained from laboratory stock and fed ground beef heart and Trouvit trout pellets (Trouw, Putten, The Netherlands) weekly. They had been adapted to a gray background (melanophore dispersion stage 3 ; Hogben and Slome, 1931), at a water temperature of $22 \pm 1^{\circ} \mathrm{C}$. For the experiments, animals were decapitated and neurointermediate lobes were dissected out.

Routine electron microscopy. In order to visualize the cell membranes in detail, lobes were fixed in $1 \%$ glutaraldehyde in $0.05 \mathrm{M}$ sodium phosphate buffer (PB) containing 1\% tannic acid for $16 \mathrm{hr}$ and postfixed in $1 \%$ osmium tetroxide in PB for $2 \mathrm{hr}$ at $4^{\circ} \mathrm{C}$. Ultrathin (pale gold) Araldite sections were mounted on Formvar-coated nickle grids, contrasted in $2 \%$ aqueous uranyl acetate $(15 \mathrm{~min})$ and lead citrate $(5 \mathrm{~min})$, and examined in a Jeol JEM 100CX II microscope.

Immunoelectron microscopy. After fixation of the lobes in $1 \%$ glutaraldehyde in PB for $2 \mathrm{hr}$, they were treated with $0.1 \%$ sodium borohydride and 50 mM glycine in PB for 15 min and cryoprotected by immersion in increasing concentrations of glycerol $(10 / 20 / 30 \%$ in PB; 30 min per concentration). After mounting on Thermanox (LAB-TEK, Miles Labs, Naperville, IL) the material was rapidly frozen in liquid propane $\left(-190^{\circ} \mathrm{C}\right)$ and transferred to a precooled chamber $\left(-90^{\circ} \mathrm{C}\right)$ of a quick-freezing apparatus (Reichert-Jung, Nussloch, Germany). Then tissues were freeze-substituted by methanol containing $0.5 \%$ uranyl acetate and warmed $4^{\circ} \mathrm{C} / \mathrm{hr}$ to $-45^{\circ} \mathrm{C}$. Embedding in Lowicryl HM20 resin (Bio-Rad, UK) was carried out in three steps with a progressively increasing ratio of resin to methanol. Polymerization of Lowicryl was performed by UV radiation $(360 \mathrm{~nm})$ at $-45^{\circ} \mathrm{C}$ for $16 \mathrm{hr}$ and, subsequently, at $20^{\circ} \mathrm{C}$ for $24 \mathrm{hr}$.

For immunocytochemistry, ultrathin sections mounted on Formvarcoated nickle grids were incubated in, cońsecutively, sodium phosphatebuffered saline (PBS; pH 7.4) containing $0.1 \%$ sodium borohydrate and 50 m glycine ( $10 \mathrm{~min})$, blocking buffer $(0.5 \% \mathrm{BSA}, 0.5 \%$ cold fish skin gelatin in PBS, $10 \mathrm{~min}$; Aurion Wageningen), anti-DA or anti-GABA or anti-NPY in this buffer (diluted 1:1000, 1:2000, and 1:2000, respectively; $16 \mathrm{hr}$ ), and goat anti-rabbit immunoglobulin $\mathrm{G}$ labeled with 10 nm gold (GAR-10, Aurion; $1.5 \mathrm{hr}$ ). Anti-DA, anti-NPY, and anti-GABA had been raised in rabbit, and their specificity has been described previously (Buijs et al., 1978, 1984; Seguela et al., 1984; Danger et al., 1985). Specificity controls of the immunocytochemical procedures included preadsorptions of the antisera with their corresponding antigens.

Double labeling was performed as described by Slot et al. (1991). Shortly after the first labeling (GAR 10; see above) sections were postfixed with $1 \%$ glutaraldehyde in PBS $(5 \mathrm{~min})$ and thoroughly washed. Then, labeling with another primary antiserum and GAR 5 was carried out. For triple labeling, the procedure was extended by staining with the third primary antiserum and GAR 15 . To study a possible crossreaction between primary antibodies and nonhomologous GAR-gold complexes, for some sections glutaraldehyde fixation was performed before instead of after staining with GAR-gold.

Morphometry. In one routinely fixed pars intermedia, 30 varicosities were photographed (final magnification, $25,000 \times$ ). The numbers of electron-lucent (LV) and electron-dense vesicles (DV) per varicosity were counted, and in each varicosity diameters of 20 electron-lucent vesicles and of all the electron-dense vesicles present were determined, using an $x-y$ tablet and a MOP-3 (Kontron, München, Germany) image analyzer.

In ultrathin sections of freeze-substituted material, labeling intensity (monolabeling) of electron-dense vesicles in varicosities was determined by counting the numbers of gold particles per vesicle. Only vesicles that revealed their limiting membrane were taken into account. To study the relation between DA and NPY labeling, the numbers of vesicles reacting with anti-DA, with anti-NPY, and with both antisera were counted. (Vesicles with only one gold particle per antiserum were discarded.)

A random selection procedure was maintained throughout the experiment. The data were analyzed with a one-way analysis of variance ( $\alpha=5 \%$; Bliss, 1967), preceded by tests for the joint assessment of normality (Shapiro and Wilk, 1965) and the homogeneity of variances (Bartlett's test; see Bliss, 1967) and followed by the multiple-range test of Duncan (Steel and Torrie, 1960).

\section{Results}

\section{Morphology of nerve endings}

In routinely prepared material the main constituents of the pars intermedia can readily be identified: melanotrope cells, folliculostellate cells, and axonal varicosities (Fig. 1). Two morpho- 


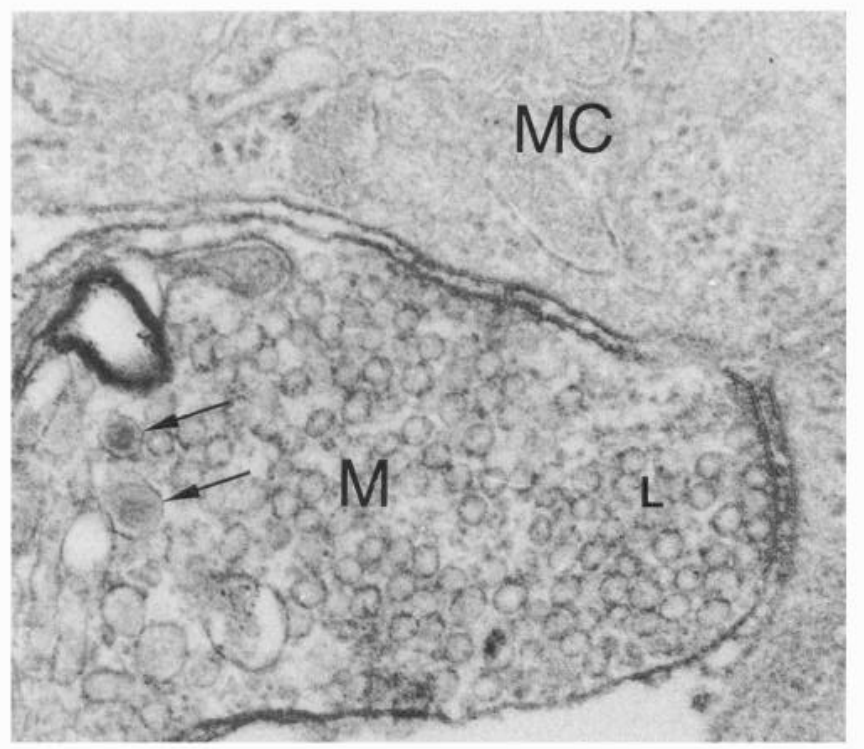

Figure 2. Type $\mathrm{M}$ varicosity profile $(M)$, abutting a melanotrope cell $(M C)$, contains many LVs $(L)$ near the contacting membrane, and only al few DVs. (arrows). Magnification, 66,500x.

logically different vesicle types are present in all profiles. One type is small and electron lucent (LV); the other type is large and electron dense (DV). The varicosity profiles were classified on the basis of the cell type(s) they abut. Type M profiles abut one (or more) melanotrope(s), type $\mathbf{S}$ contacts one (or more) folliculostellate cell(s), and type MS contacts both cell types (Figs. 2-4). In type M varicosities, LVs tend to be preferentially located near sites of the plasma membrane that are adjacent to melanotropes and strongly outnumber the DVs, which occur in a randomlike fashion throughout the cytoplasm (Table 1; ratio $L V: D V=15.8)$. In comparison, in S-type varicosities, LVs are more dispersed and relatively less numerous, whereas the DVs

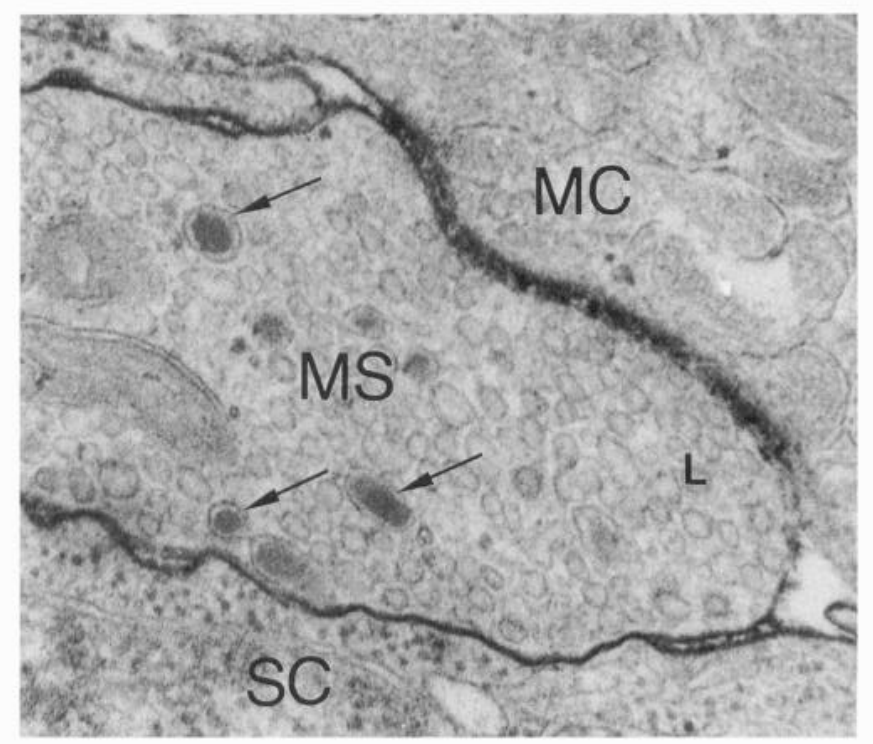

Figure 3. Type MS varicosity profile $(M S)$ abutting a melanotrope cell $(M C)$ as well as a folliculostellate cell $(S C)$, with the two vesicle types ( $L$, LVs; arrows, DVs). Plasma membranes are highly distinct because of the use of tannic acid in the fixative. Magnification, 66,500x.

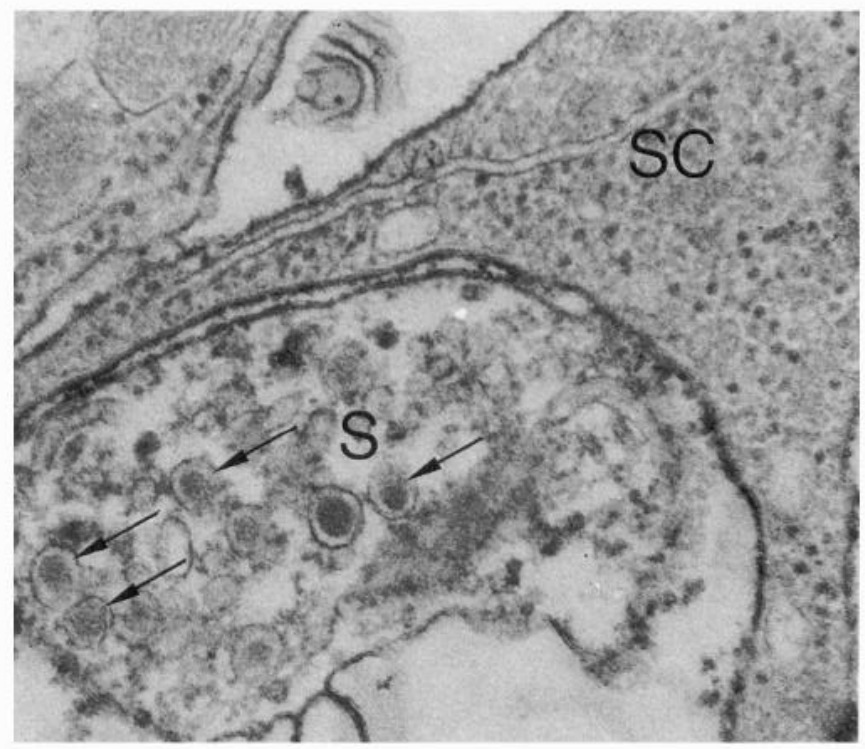

Figure 4. Type $\mathrm{S}$ varicosity profile $(S)$ abutting a folliculostellate cell $(S C)$ in which DVs (arrows) are prominent. Note the low number of LVs. Magnification, $66,500 \times$.

are more abundant (LV:DV $=3.3)$. Type MS varicosities show an intermediate picture (LV:DV = 7.2; see also Table 1). Mean diameters of LVs and DVs are remarkably constant in all three varicosity types, namely, 48 and $94 \mathrm{~nm}$, respectively (Table 1). Histograms of the diameters of individual vesicles show statistically normal distributions for both vesicle types in each of the three varicosity types (Fig. 5).

\section{Immunocytochemistry}

Tissue ultrastructure of freeze-substituted material appeared well preserved and very similar to that of routinely stained tissue, except for LVs, which are less clearly individually delineated from the cytoplasm. Nevertheless, clusters of LVs, found in the routinely fixed material, could still be easily identified. The following data apply to all of the three varicosity types.

Controls. After immunolabeling with the three antisera adsorbed to their corresponding antigens, no appreciable amount of immunoreactivity was observed in any of the experiments. Similarly, cross-fixation with glutaraldehyde fully abolished immunolabeling.

Monolabeling. Immunogold labeling on sections of the pars intermedia with anti-DA showed immunoreactivity in approximately $90 \%$ of the varicosities. Although some gold particles were found in the cytoplasm, most of the particles were present

Table 1. Distribution of LVs and DVs in varicosity profiles contacting melanotrope cells (M), folliculostellate cells (S), or both (MS) (means \pm SEM; $n=18$ )

\begin{tabular}{lcll} 
Varicosity profile & M & MS & S \\
\hline Number LV & $80.6 \pm 11.6^{\mathrm{s}}$ & $52.1 \pm 12.3$ & $32.7 \pm 7.2^{\mathrm{M}}$ \\
Number DV & $5.1 \pm 0.8^{\mathrm{s}}$ & $7.2 \pm 1.0$ & $10.0 \pm 1.0^{\mathrm{M}}$ \\
Ratio LV:DV & 15.8 & 7.2 & 3.3 \\
Diameter LV (nm) & $48 \pm 1$ & $48 \pm 1$ & $48 \pm 1$ \\
Diameter DV (nm) & $93 \pm 13$ & $93 \pm 10$ & $94 \pm 9$
\end{tabular}

Superscripts show statistic differences with the other groups $(p<0.01)$. 


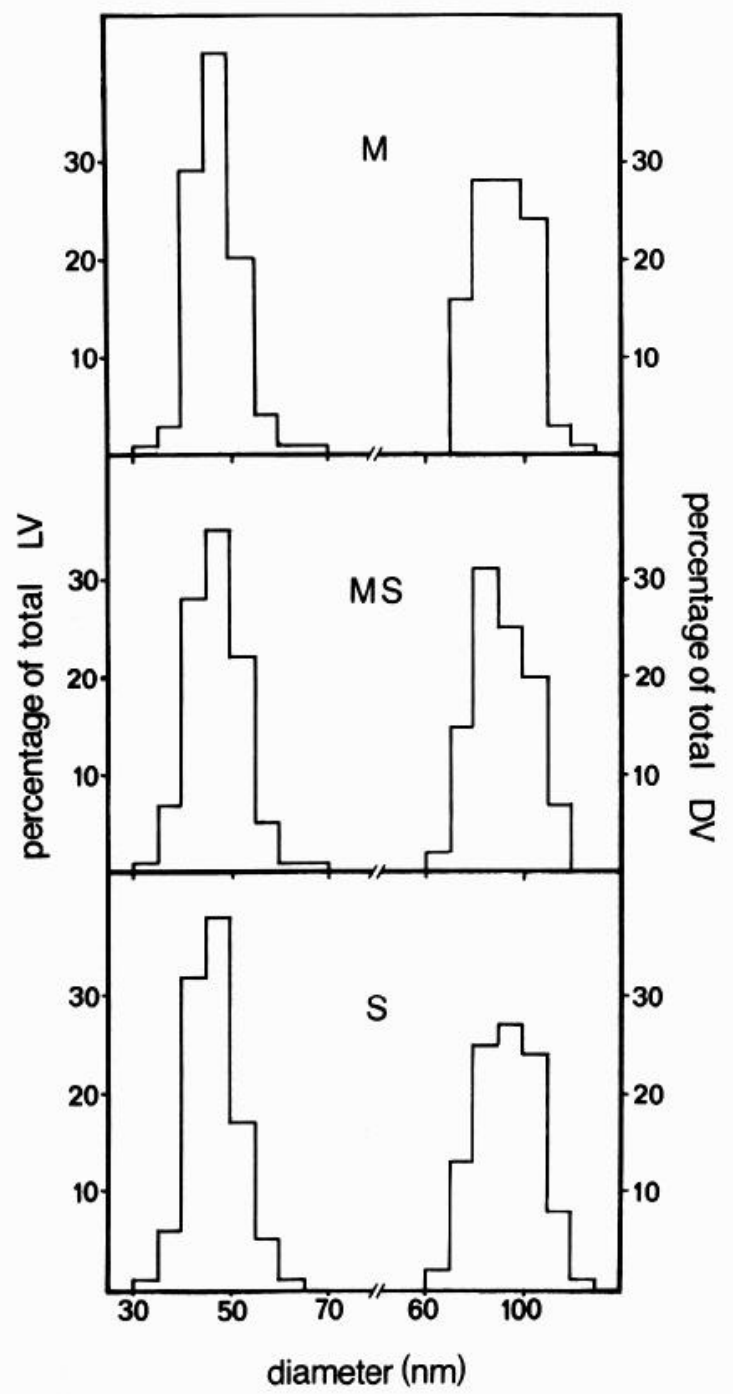

Figure 5. Histograms of the diameters of individual vesicles $(L V, D V)$ in varicosities abutting melanotropes $(M)$, folliculostellate cells $(S)$, or both cell types $(M S)(n=200$ for LV in M type, MS type, and S type profiles; $n=87$ for DV in M type profiles; $n=140$ for DV in MS type profiles; $n=197$ for DV in S type profiles).

on DVs, about $25 \%$ of which were immunopositive (Table 2 , $\mathrm{DA}_{\mathrm{ir}} / \mathrm{DV}_{\text {total }}$; Fig. 6). Labeling intensity (number of gold particles) per vesicle was fairly high, following a distribution of Poisson (Fig. 7A). After immunolabeling with anti-GABA, immu-

Table 2. Percentage immunolabeling of all $\mathrm{DVs}$ present $\left(\mathrm{DV}_{\text {total }}\right)$ or of all immunoreactive $\mathrm{DVs}\left(\mathrm{DV}_{\mathrm{ir}}\right)$ with anti-DA only $\left(\mathrm{DA}_{\mathrm{tr}}\right)$, with antiNPY only (NPY $\left.{ }_{i r}\right)$, or with both antisera, (DA + NPY)

(means \pm SEM; $n=30$ )

\begin{tabular}{llll} 
Immunolabeling & Anti-DA & Anti-NPY & $\begin{array}{l}\text { Anti-DA } \\
\text { and } \\
\text { Anti-NPY }\end{array}$ \\
\hline $\mathrm{DA}_{\text {ir }} / \mathrm{DV}_{\text {total }}$ & $25.2 \pm 1.6$ & - & $17.5 \pm 1.6$ \\
$\mathrm{NYP}_{\mathrm{ir}} / \mathrm{DV}_{\text {total }}$ & - & $63.7 \pm 3.3$ & $50.7 \pm 2.7$ \\
$\mathrm{Unllabeled} / \mathrm{DV}_{\text {total }}$ & $74.9 \pm 1.6$ & $38.9 \pm 2.8$ & $30.1 \pm 2.0$ \\
$\mathrm{DA}_{\mathrm{ir}} / \mathrm{DV}_{\text {ir }}$ & - & - & $11.8 \pm 1.8$ \\
$\mathrm{NPY}_{\mathrm{ir}} / \mathrm{DV}$ & - & - & $71.7 \pm 2.4$ \\
$(\mathrm{DA}+\mathrm{NPY})_{\mathrm{ir}} / \mathrm{DV}_{\mathrm{ir}}$ & - & - & $15.7 \pm 1.5$ \\
\hline
\end{tabular}

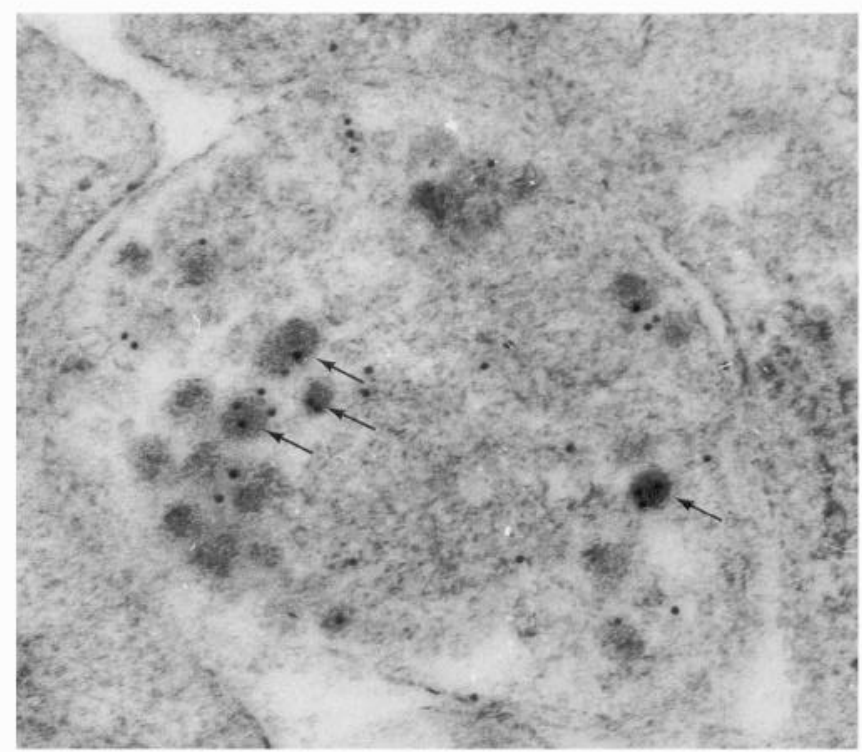

Figure 6. Anti-DA-immunoreactive varicosity with gold particles, many of which are on DVs (arrows). Freeze-substitution. Magnification, $70,300 \times$.

noreactivity was present in all varicosity profiles. GABA immunoreactivity was primarily found in association with the clusters of the LVs (Fig. 8). Only a few DVs could be found to be immunopositive. Immunolabeling with anti-NPY appeared in $90 \%$ of the varicosities, with $64 \%$ of the DVs covered with gold particles (Table 2, NPY ir $/ \mathrm{DV}_{\text {toat }}$; Fig. 9). Labeling intensities varied from 1 to 10 particles per vesicle and also showed a Poisson distributed pattern (Fig. 7B). The number of gold particles above the cytoplasm and LVs was very low.

Double and triple labeling. Double immunogold labeling for DA and GABA revealed that the DVs were exclusively im-

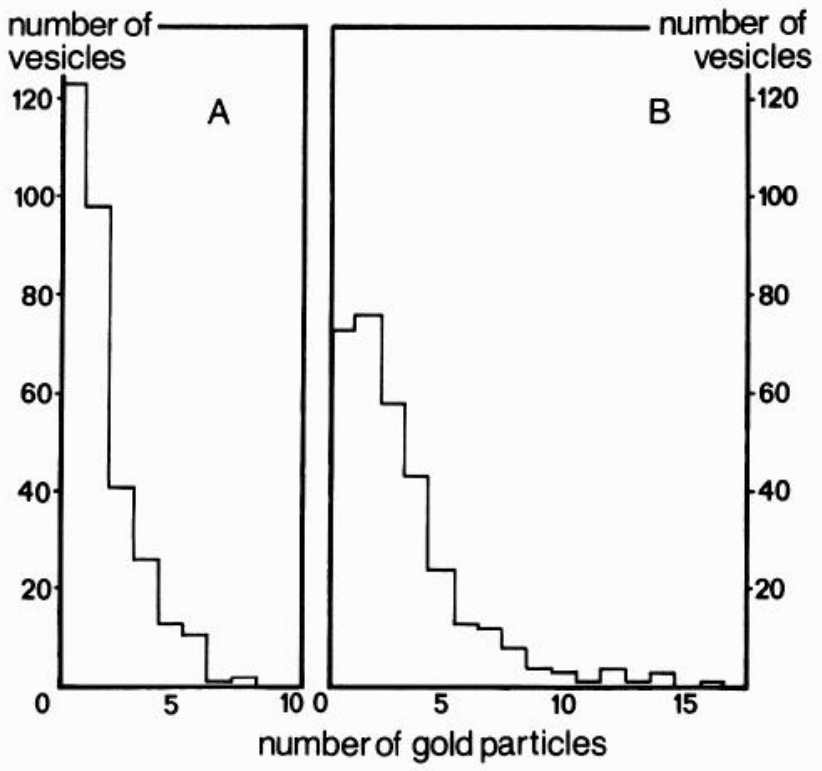

Figure 7. Histograms of the number of gold particles per DV after immunolabeling with anti-DA $(A)$ or with anti-NPY $(B)(n=310$ for DV immunoreactive with anti-DA; $n=324$ for DV immunoreactive with anti-NPY). 


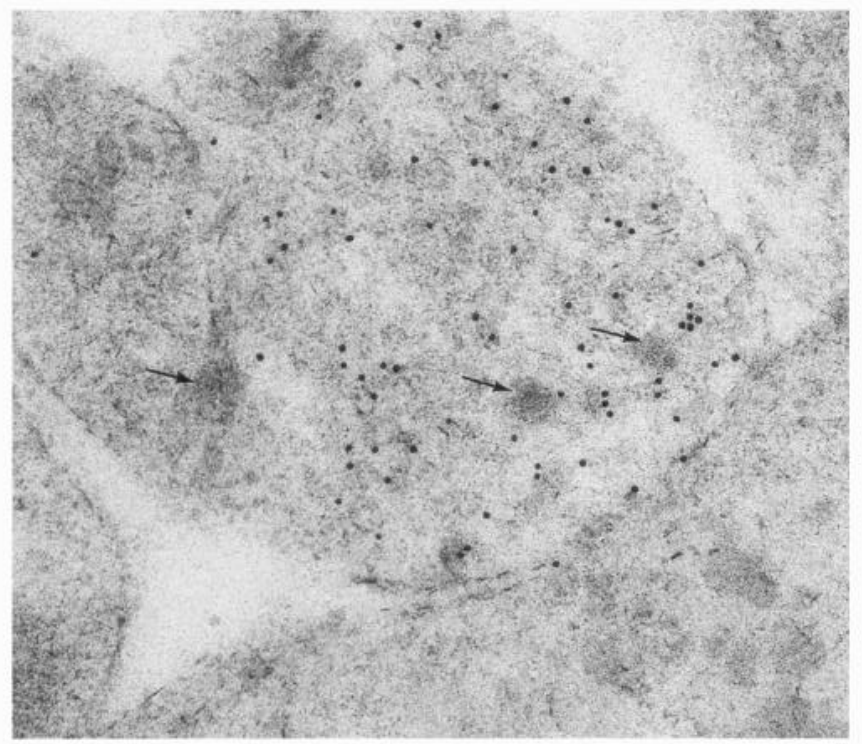

Figure 8. Anti-GABA-immunoreactive varicosity in the pars intermedia. Gold particles are associated with clusters of LVs; DVs are immunonegative (arrows). Magnification, 66,500×.

munopositive with anti-DA (GAR 10) whereas immunoreactivity to GABA appeared to be preferentially associated with the clusters of LVs and occurred only in a few DVs (Fig. 10). Vesicles reacting with both anti-DA and anti-GABA were only rarely found. The percentage of DVs that were labeled with antiDA was not significantly different from that in the double labeling procedure. The same applied to the labeling with antiGABA. Double labeling for GABA and NPY showed anti-GABA immunoreactivity on the clusters of LVs (GAR 5) and antiNPY-immunoreactive DVs (GAR 10; Fig. 11). In a few cases DVs were immunoreactive for both anti-GABA and anti-NPY. Percentages of vesicles labeled with anti-GABA and anti-NPY after double labeling procedures were similar to those after

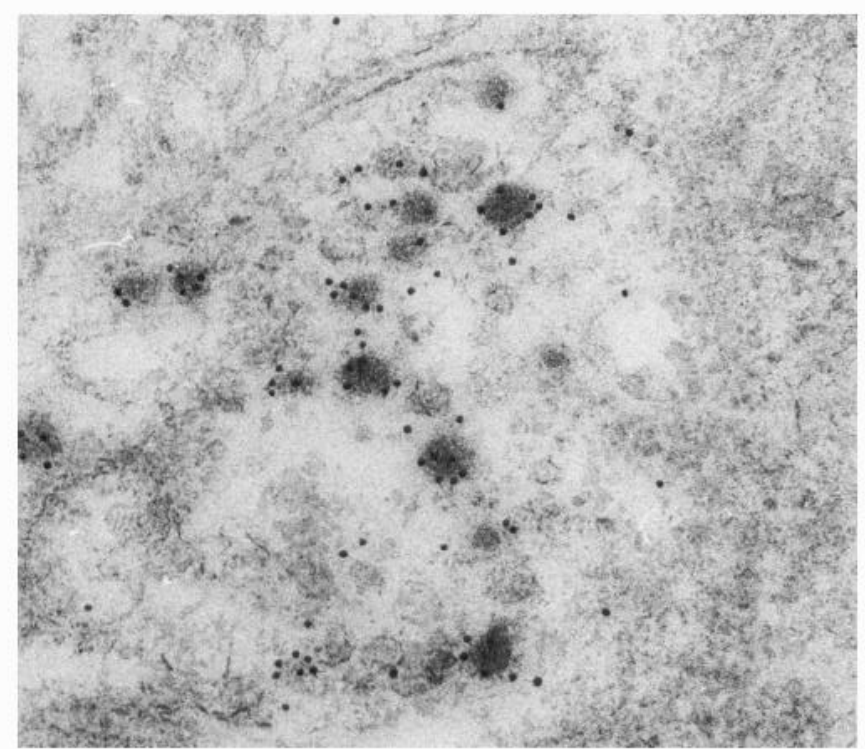

Figure 9. Anti-NPY-positive varicosity with gold particles on DVs. Magnification, $80,275 \times$.

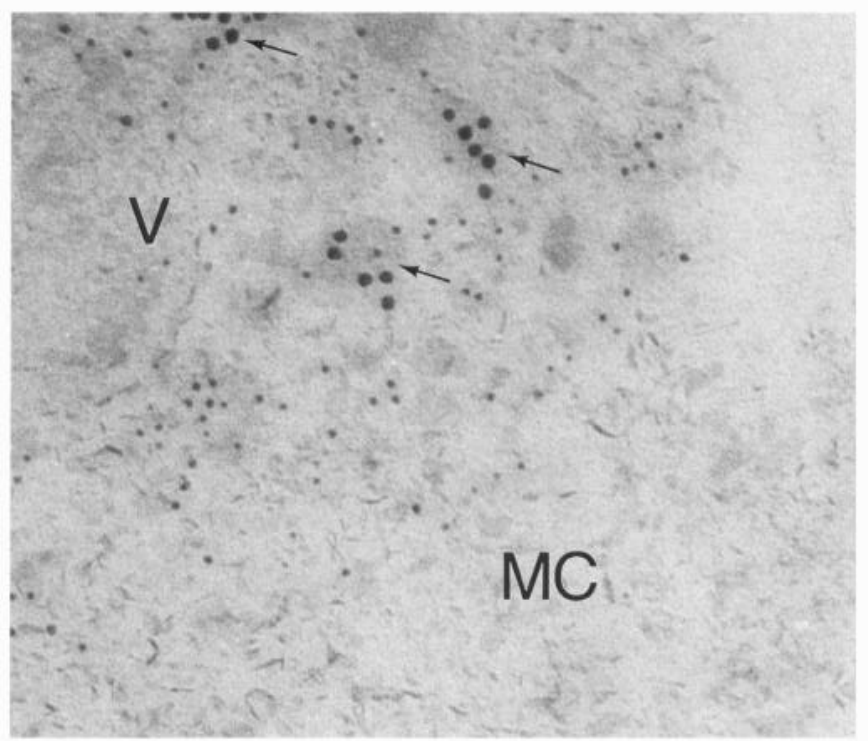

Figure 10. Varicosity $(V)$ double labeled with anti-GABA $(5 \mathrm{~nm})$ associated with clusters of LVs and anti-DA $(10 \mathrm{~nm})$ on DVs (arrows). $M C$, melanotrope cell. Magnification, $133,000 \times$.

monolabeling. After double labeling with anti-DA $(10 \mathrm{~nm})$ and anti-NPY (5 nm), reactivity was found only on DVs (Fig. 12). Quantification showed that $12 \%$ of the labeled DVs were only stained with anti-DA (Table $2, \mathrm{DA}_{\mathrm{ir}} / \mathrm{DV}_{\mathrm{ir}}$ ), $72 \%$ only with antiNPY (Table 2, NPY ${ }_{\text {ir }} / \mathrm{DV}_{\mathrm{ir}}$ ), and $16 \%$ were labeled with both antisera [Table 2, (DA and NPY) $)_{\mathrm{ir}} / \mathrm{DV}_{\mathrm{ir}}$ ). (A vesicle was considered to be labeled when the number of a particular type of gold particle was two or more). Labeling intensities with each antiserum after double labeling (i.e., percentage of DVs that did immunoreact) were considerably lower than those after monolabeling. Immunoreactivity to anti-DA was reduced to $69 \%$ (percentage of anti-DA-immunoreactive DVs after double labeling $\div$ percentage of anti-DA-immunoreactive DVs after monolabeling $\times 100 \%$; Table 2). Immunoreactivity to antiNPY was reduced to $80 \%$ (percentage of anti-NPY-immunoreactive DVs after double labeling $\div$ percentage of anti-NPYimmunoreactive DVs after monolabeling; see also Table 2).

After triple labeling with anti-GABA $(5 \mathrm{~nm})$, anti-DA $(10$ $\mathrm{nm})$, and anti-NPY $(5 \mathrm{~nm})$, only varicosity profiles were labeled. Although some background labeling was apparent and ultrastructure, especially of secretory vesicles, was less well preserved than after mono- or double labeling, immunoreactivity clearly appeared in all three varicosity profiles. More than $50 \%$ showed immunoreactivity with all three sera (Fig. 13).

\section{Discussion}

\section{Technical aspects}

The high specificity of the antisera used in the present study has been demonstrated in various control experiments including preadsorptions of the antisera with their corresponding antigens (anti-GABA: Buijs et al., 1978; Seguela et al., 1984; anti-DA: Buijs et al., 1984; Geffard et al., 1984; anti-NPY: Danger et al., 1985). Therefore, it can be concluded that immunostaining with anti-GABA, anti-DA, and anti-NPY reflects the presence of GABA, DA, and NPY, respectively.

The common method to demonstrate DA at the ultrastructural level involves preembedding immunostaining using the 


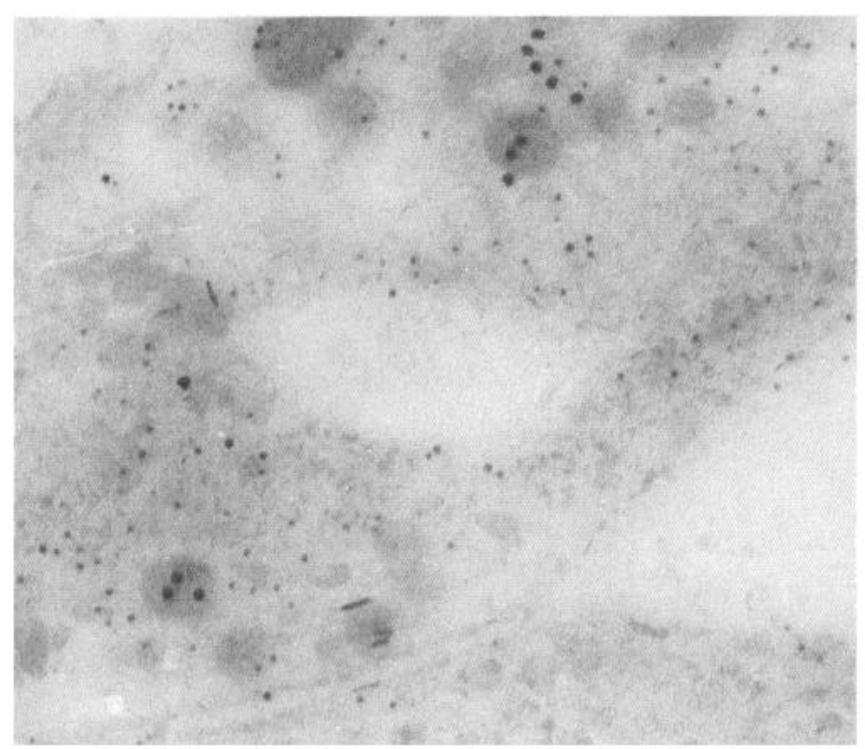

Figure 11. Varicosity, double labeled with anti-GABA $(5 \mathrm{~nm})$ associated with clusters of LVs and anti-NPY $(10 \mathrm{~nm})$ on DVs. Magnification, $123,500 \times$.

peroxidase-antiperoxidase/diaminobenzidine staining (e.g., Buijs et al., 1984). In the present study, freeze substitution has been used to obtain optimal tissue preservation. Moreover, the postembedding immunogold staining enables a much more precise localization of immunogold particles (in our case on the DVs) than can be achieved with the diaminobenzidine reaction products in the preembedding procedure.

\section{Cellular storage of messengers}

From a previous immunocytochemical study, we have concluded that GABA and NPY coexist within axonal varicosities in the intermediate lobe of Xenopus laevis (de Rijk et al., 1990). The present immunoelectron microscope investigations show that in addition to NPY and GABA, DA is present in (nearly) all of these varicosities. This triple coexistence can be easily deduced from the three combinations of double staining but is directly revealed by triple staining.

Coexistence of two different types of messenger in one neuron has been frequently described (e.g., Hökfelt et al., 1986), but as far as we know the presently observed coexistence of an amino acid, a neuropeptide, and a catecholamine within the same synaptic element has not been reported before. The question arises as to the physiological significance of this coexistence. Since three messengers are known to inhibit the release of $\alpha \mathrm{MSH}$ from Xenopus pars intermedia in vitro (Verburg-van-Kemenade et al., 1986a, 1986b), the varicosities may play a very important role in the physiological inhibition of $\alpha \mathrm{MSH}$ release from the melanotrope cells, that is, when the animal has to adapt to a white background by reducing $\alpha \mathrm{MSH}$ release from the pars intermedia. The possibility that the three messengers act in a synergistical way, reinforcing the action of each other, is presently under investigation.

\section{Vesicular storage of messengers}

A previous immunocytochemical study on the axonal varicosities in the intermediate lobe of $X$. laevis has indicated that NPY is present within DVs, whereas GABA would be associated with

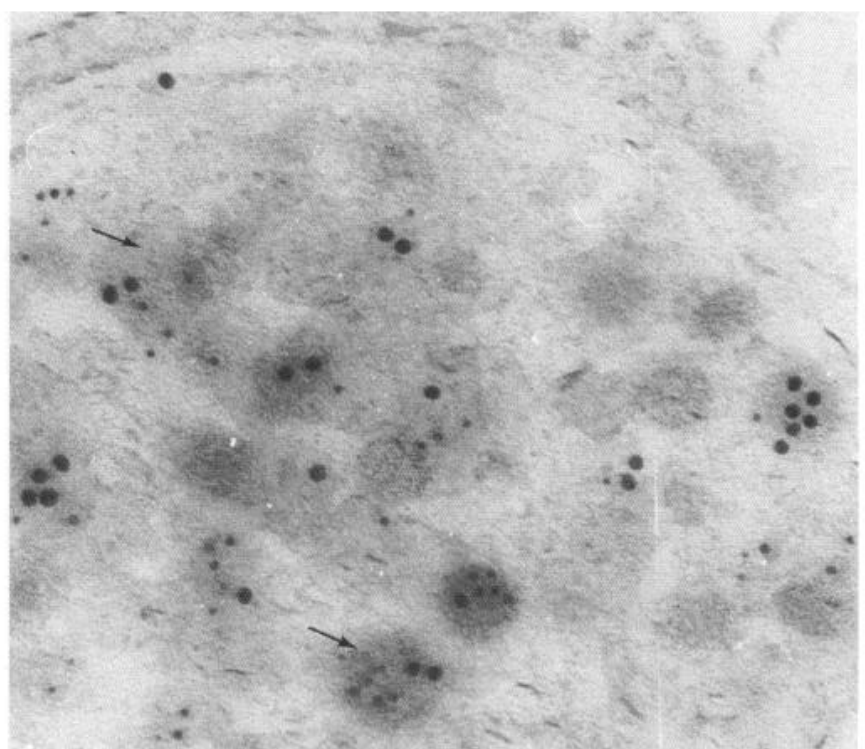

Figure 12. Varicosity, double labeled with anti-NPY $(5 \mathrm{~nm})$ and antiDA $(10 \mathrm{~nm})$. Gold particles are exclusively present on DVs. On some DVs gold of both sizes occurs (arrows); on the other DVs either $5 \mathrm{~nm}$ or $10 \mathrm{~nm}$ gold particles are present. Magnification, 142,500x.

the LVs (de Rijk et al., 1990). The present quantitative immunomonolabeling studies support this idea because they show that the majority of DVs are NPY immunopositive and that GABA immunoreactivity is nearly exclusively associated with the clusters of LVs. Moreover, the studies demonstrate that DA also is present within DVs.

Triple labeling clearly reveals that NPY and DA can coexist within the same DV. The triple immunolabeling procedure precludes a quantitative assessment of the degree of coexistence, because the ultrastructure of the tissue is not optimally preserved. Poor tissue preservation is the result of the complex

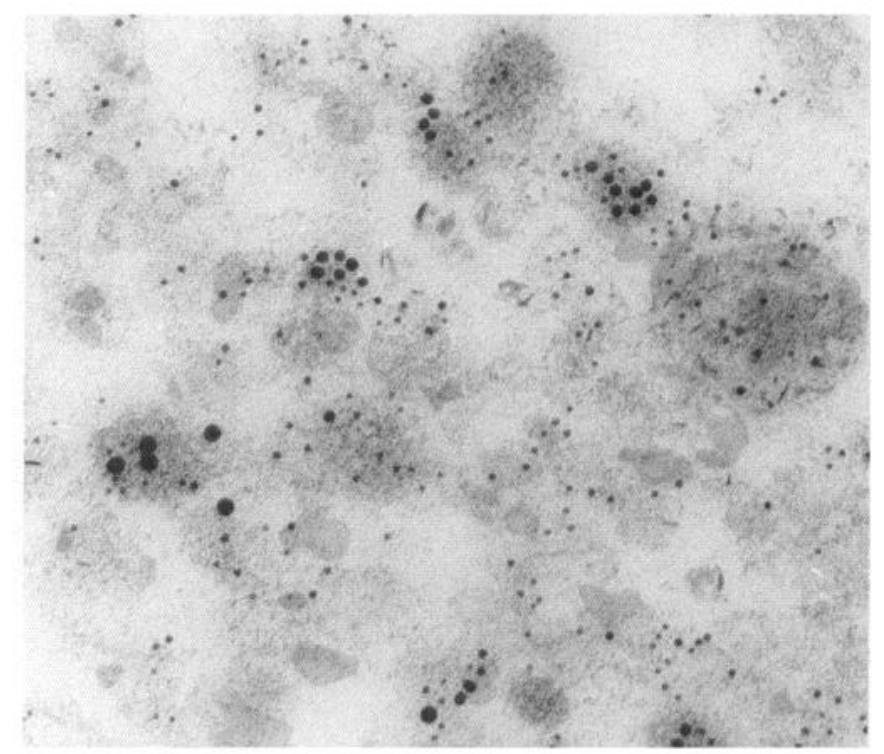

Figure 13. Varicosity triple labeled with anti-GABA $(5 \mathrm{~nm})$, anti-DA $(10 \mathrm{~nm})$, and anti-NPY $(15 \mathrm{~nm})$, demonstrating the presence of antiDA and anti-NPY immunoreactivities in DVs, whereas anti-GABA immunoreactivity is associated with the clusters of LVs. Magnification, $114,000 \times$. 
chemical treatment of the sections, rendering the identification of the secretory granules rather difficult. The quantitative distribution of gold particles over DVs can be more readily investigated in double-labeled sections, because here tissue ultrastructure appears to be adequately conserved. Of the DVs, $16 \%$ are stained with both anti-DA and anti-NPY. This percentage seems to be rather low, but based on the following arguments we conclude that this is a considerable underestimation of the actual degree of coexistence. First, double labeling procedures reduce the labeling intensities, for example, by steric hindrance (viz. to $69 \%$ for anti-DA and to $80 \%$ for anti-NPY). Correction for this reduction indicates that about $25 \%$ of the vesicles costore DA and NPY. Second, the contents of some vesicles (estimated at about $15 \%$ ) will not have been exposed to the antibodies because they have been cut tangentially. Third, the respective immunostainings may not have been maximally effective because tissue processing interferes with preservation and/or accessibility of antigenic determinants. Finally, it is well known that secretory vesicles with different chemical contents often have different morphology, in particular as to their size (e.g., Wendelaar Bonga, 1970; Burgess and Kelly, 1987). Since the present data on unlabeled, routinely fixed material show that the DVs possess a normal size distribution, the vesicles seem to belong to one morphologically homogeneous population and, hence, may well have chemically the same contents. Taking these arguments together, it should be concluded that the majority if not all DVs costore DA and NPY.

There has been an earlier report on costorage of a biogenic amine and a neuropeptide in the same (DV) vesicle, namely, 5-HT and substance P (Pelletier et al., 1981). However, costorage of DA and NPY within the same secretory vesicle has not been described before, which may be largely due to the fact that preembedding methods do not allow for accurate subcellular localization of DA. Nevertheless, this type of storage may be a common phenomenon because the combined presence of the DA and NPY has been suggested in locus coeruleus by mRNA studies of NPY and tyrosine hydroxylase after reserpine treatment (Foster et al., 1991). Vesicular coexistence of DA and NPY strongly indicates that both messengers are co-released, which would be in line with the suggestion that DA and NPY inhibit $\alpha \mathrm{MSH}$ release from Xenopus melanotropes by acting synergistically.

The mechanism of this inhibition appears to be rather complex, GABA and DA acting directly but NPY acting indirectly, via folliculostellate cells, on the melanotrope cells (de Koning et al., 1991). Consequently, it might be expected that GABAcontaining vesicles would be preferentially located in varicosity profiles that abut melanotrope cells (type M) whereas NPYcontaining vesicles would be located especially in type $S$ profiles. As to GABA and NPY, this expectation appears to be fulfilled: in type $S$ profiles the ratio between LVs and DVs is about five times as high as in type $M$ profiles. On the other hand, the preferential presence of (DA-containing) DVs in type $S$ profiles seems to be conflicting with a direct action of DA on melanotropes. However, the possibility should be considered that DA released from type $S$ varicosities (or varicosity sites near folliculostellate cells) acts, via diffusion ("paracrine communication") through the intercellular space, on melanotrope cells. The mechanism of DA packaging in type $S$ and type $M$ varicositics is not known. It may be speculated that type $S$ and $M$ varicosities have DA reuptake mechanisms that are able to fill NPY-containing vesicles with DA. It will be of interest to study whether or not type M, S, and MS profiles correspond (1) to different crosssectional planes of the same varicosities, (2) to different varicosity profiles of the same neurons, or (3) even to different neurons.

In conclusion, the present qualitative and quantitative data on the subcellular presence of GABA, DA, and NPY seem to fit well with the anatomical and physiological characteristics of the mechanisms of neural inhibition of $\alpha \mathrm{MSH}$ release from Xenopus melanotropes, and may add to the insight into the release dynamics and physiological significance of coexisting neurochemical messengers.

\section{References}

Bliss CJ (1967) Statistics in biology, Vol 1. New York: McGraw-Hill. Brussaard A, Schluter NCM, Ebberink RHM, Kits KS, Ter Maat A (1991) Discharge induction in molluscan peptidergic cells requires a specific set of four autoexcitatory neuropeptides. Neuroscience 39: 479-492.

Buijs RM, Van Vulpen EHS, Geffard M (1978) Ultrastructural localization of GABA in the supraoptic nucleus and neural lobe. Neuroscience 20:347-355.

Buijs RM, Geffard M, Pool CW, Hoorneman EMD (1984) The dopaminergic innervation of the supraoptic and paraventricular nucleus. A light and electron microscopical study. Brain Res 323:65-72.

Burgess TL, Kelly RB (1987) Constitutive and regulated secretion of proteins. Annu Rev Cell Biol 3:243-293.

Danger JM, Guy J, Benyamina M, Jegou S, Leboulanger F, Cote J, Tonon MC, Pelletier G, Vaudry H (1985) Localization and identification of neuropeptide Y (NPY) in frog brain. Peptides 6:12251236.

de Koning HP, Jenks BG, Scheenen WJJM, de Rijk EPCT, Caris RTJM, Roubos EW (1991) Indirect action of elevated potassium and neuropeptide $\mathrm{Y}$ on $\alpha \mathrm{MSH}$ secretion from the pars intermedia of Xenopus laevis: a biochemical and morphological study. Neuroendocrinology 54:68-76.

de Rijk EPCT, Jenks BG, Roubos EW (1990) GABA and neuropeptide $Y$ co-exist in axons innervating the neurointermediate lobe of the pituitary of Xenopus laevis - an immunoelectron microscopic study. Neuroscience 38:495-502.

de Rijk EPCT, Cruijsen PMJM, Jenks BG, Roubos EW (1991) 125IBolton-Hunter neuropeptide $Y$ binding sites on folliculo-stellate cells of the pars intermedia of Xenopus laevis. Endocrinology 128:735740.

Everitt BJ, Hökfelt T, Wu J-Y, Goldstein M (1984) Coexistence of tyrosine hydroxylase-like and gamma-amino-butyric acid-like immunoreactivities in neurons of the arcuate nucleus. Neuroendocrinology 39:189-191.

Foster OJF, Biswas S, Lightman SL (1991) Neuropeptide Y and tyrosine hydroxylase mRNA levels in the locus coeruleus show similar increases after reserpine treatment. Neuropeptides 18:137-141.

Geffard M, Buijs RM, Seguela PT, Pool CW, Le Moal M (1984) First demonstration of highly specific sensitive antibodies against dopamine. Brain Res 294:161-165.

Hogben L, Slome D (1931) The pigmentary effector system: the dual character of endocrine coordination in amphibian color change. Proc R Soc Lond [Biol] 108:10-53.

Hökfelt T, Lundberg JM, Lagercrantz H, Tatemoto K, Mutt V, Terenius L, Everitt BJ, Fuxe K, Agnati LF, Goldstein M (1983) Occurrence of neuropeptide Y (NPY)-like immunoreactivity in catecholamine neurons in the human medulla oblongata. Neursci Lett 36:217-222.

Hökfelt T, Holets VR, Staines W, Meister B, Melander T, Schalling M, Schultzberg M, Freedman J, Björklund H, Olson L, Lindh B, Elfvin L, Lundberg JM, Lindgren JA, Samuelsson B, Pernow B, Terenius L, Post C, Everitt B, Goldstein M (1986) Coexistence of neuronal messengers-an overview. Prog Brain Res 68:33-78.

Kagotani Y, Tsuruo Y, Hisano S, Daikoku S, Chihara K (1989) Synaptic regulation of paraventricular arginine vasopressin-containing neurons by neuropeptide $\mathrm{Y}$-containing monoaminergic neurons in rats. Electron-microscopic triple labeling. Cell Tissue Res 257:269278.

Meister B, Hökfelt T, Vale WW, Goldstein M (1985) Growth hormone releasing factor (GRF) and dopamine coexist in hypothalamic arcuate neurons. Acta Physiol Scand 124:133-136. 
Merighi A, Polak JM, Fumagalli G, Theodosis DT (1989) Ultrastructural localization of neuropeptides and GABA in the rat dorsal horn: an immunogold study. J Histochem Cytochem 37:529-540.

Pelletier G, Steinbusch HWM, Verhofstad AAJ (1981) Immunoreactive substance $P$ and serotonin present in the same dense-core vesicles. Nature 293:71-72.

Scheller RH, Jackson JF, McAllister LB, Rothman BS, Mayeri E, Axel $R$ (1983) A single gene encodes multiple neuropeptides mediating a stereotyped behaviour. Cell 32:7-22.

Seguela P, Geffard M, Buijs RM, Le Moal M (1984) Anti-bodies against $\gamma$-aminobutyric acid: specificity studies and immunocytochemical results. Proc Natl Acad Sci USA 81:3888-3892.

Shapiro HH, Wilk MB (1965) An analysis of variance test for normality. Biometry $52: 591-611$.

Slot JW, Geuze HJ, Gigengack S, Leinhard GE, James DE (1991) Immuno-localization of the insulin regulatable glucose transporter in brown adipose tissue of the rat. J Cell Biol 113:123-135.

Steel RGD, Torrie JH (1960) Principles and procedures in statistics. New York: McGraw-Hill.

Takeda N, Inagaki S, Shiosaka S, Taguchi Y, Oertel WH, Tohyama M, Watanabe T, Wada H (1984) Immunohistochemical evidence for coexistence of histidine decarboxylase-like and glutamate decarboxylase-like immunoreactivities in nerve cells of the magnocellular nucleus of the posterior hypothalamus of rats. Proc Natl Acad Sci USA 81:7647-7650.

Verburg-van Kemenade BML, Jenks BG, Driessen AGJ (1986a) GABA and dopamine act directly on melanotropes of Xenopus to inhibit MSH-secretion. Brain Res Bull 17:697-704.
Verburg-van Kemenade BML, Tappaz M, Paut L, Jenks BG (1986b) GABAergic regulation of melanocyte-stimulating hormone secretion from the pars intermedia of Xenopus laevis: immunocytochemical and physiological evidence. Endocrinology 118:260-267.

Verburg-van Kemenade BML, Tonon MC, Jenks BG, Vaudry H (1986c) Characteristics of receptors for dopamine in the pars intermedia of the amphibian Xenopus laevis. Neuroendocrinology 44:446-456.

Verburg-van Kemenade BML, Jenks BG, Danger JM, Vaudry H (1987a) An NPY-like peptide may function as MSH-inhibiting factor in $\mathrm{Xe}$ nopus laevis. Peptides 8:61-66.

Verburg-van Kemenade BML, Jenks BG, Visser TJ, Tonon MC, Vaudry H (1987b) Assessment of TRH as a potential MSH-release stimulating factor in Xenopus laevis. Peptides 8:69-76.

Verburg-van Kemenade BML, Jenks BG, Cruijsen PMJM, Dings A, Tonon MC, Vaudry H (1987c) Regulation of MSH-release from the neurointermediate lobe of Xenopus laevis by CRF-like peptides. Peptides 8:1093-1100.

Verburg-van Kemenade BML, Jenks BG, Lenssen FJA, Vaudry H (1987d) Characteristics of $\gamma$-aminobutyric acid receptors in the neurointermediate lobe of the amphibian Xenopus laevis. Endocrinology 120:622-628.

Vuillez P, Carbajo Pérez S, Stoeckel ME (1987) Colocalization of GABA and tyrosine hydroxylase immunoreactivities in axons innervating the neurointermediate lobe of the rat pituitary: an ultrastructural immunogold study. Neurosci Lett 79:53-58.

Wendelaar Bonga SE (1970) Ultrastructure and histochemistry of neurosecretory cells and neurohaemal areas in the pond snail Lymnaea stagnalis (L.). Z Zellforsch Mikrosk Anat 94:190-224. 